\title{
CLOSE ENCOUNTERS OF THE LETHAL KIND: THE USE OF DEADLY FORCE IN SELF-DEFENSE
}

\author{
Lance K. STell* \\ INTRODUCTION
}

Should the law give private individuals conditional permission to use deadly force in their own defense? Moral considerations pull both ways. On one side is the popular idea that each individual should possess a personal privilege to use deadly force in self-defense because the Constitution explicitly guarantees the right to life. Statutory law shows proper respect for the latter by recognizing the former. ${ }^{1}$ According to such a view, it would be inconsistent, if not perverse, to affirm the right to life but refuse to permit the use of means reasonably thought necessary to repel aggressive threats to selfpreservation. In the popular mind, bona fide uses of this personal privilege are laudatory and not merely exculpatory. On the other side is the idea that killings, of whatever kind, are serious wrongs and that the law ought not permit them except when they serve a compelling social purpose. Sir Matthew Hale, writing in 1678, articulated this idea as follows:

If a man kill another by misfortune, yet he shall forfeit his goods in strictness of law, in respect of the great favour the law hath to the life of a man, and to the end that men should use all care, diligence and circumspection in all they do, that no such hurt ensue by their actions. ${ }^{2}$

Copyright (@) 1986 by Law and Contemporary Problems

* Professor of Philosophy, Davidson College, Davidson, North Carolina.

1. For instance, a controversial statute enacted by the Nebraska legislature over the governor's veto would have made the "right of self-defense" a robust "right" and not merely a defense available to a charge of homicide:

Be it enacted by the people of the State of Nebraska:

Section 1. No person in this state shall be placed in legal jeopardy of any kind whatsoever for protecting, by any means necessary, himself, his family, or his real or personal property, or when coming to the aid of another who is in imminent danger of or the victim of aggravated assault. armed robbery, holdup, rape, murder, or any other heinous crime.

When substantial question of self-defense in such a case shall exist, which needs legal investigation or court action for the full determination of the facts, and the defendant's actions are subsequently found justified under the intent of this section, the State of Nebraska shall indemnify or reimburse such a defendant for all loss of time, legal fees, court costs or other expense involved in his defense.

Law of June 5, 1969, ch. 233, § 1 (codified at 1969 Neb. Rev. Stat. \$ 29-114) (quoted in Balm \& Baum, Law of Self-Defense 58 (1970)), repealed by Law of Aug. 27, 1971, Neb. LB 187. \$ 1. Nebraska's current self-defense law is found at 1979 Neb. Rev. STAT. $\$ \$ 28-140910-1417$.

2. N. Hurnard, The King's Pardon for Homicide Before A.D. 1307. at 298 (1969). The stringency of the duty to take care that one's actions not cause the death of another person is difficule for us to comprehend fully. First, we have trouble seeing the justification for what came very close to 
Nevertheless, allowing private individuals to use deadly force in their own defense has a long history. Statutes expressly privileging the use of lethal force against felons in self-defense are found as early as the sixteenth century. An English statute in 1532 removed the threat of punishment from those good citizens who killed robbers, murderers, and burglars in self-defense. ${ }^{3}$ This early statute did not, however, create any blanket right to use deadly force in self defense. In fact, by restricting the permissible use of deadly force to encounters with felons, the $\mathbf{1 5 3 2}$ statute seems to have partially deputized private individuals to act on behalf of the whole community. ${ }^{4}$ If this observation is true, the statute's justification appealed to the public interest against felonious persons and not to a private interest in self-protection. Two considerations are offered in support of this claim. Defensive killings not involving felonious assault remained punishable by forfeiture of property and, even if excusable, required the king's pardon. ${ }^{5}$ In a potentially deadly

strict liability for homicide. Second, we tend to forget that life was then much more fragile than now. The most trivial injuries might have caused death. Minor cuts frequently became septic. Grave complications often attended knocks on the head. Many people died as a result of broken bones. Almost any sort of injury could prove fatal. Thus, a man might show very great restraint in warding off an aggressor, taking pains not to strike a vital area, but in using any degree of force might inflict an injury which in some months' time resulted in death.

3. The 1532 statute said that a person who killed anyone attempting to rob him in his own house or on or near the highway should not incur a forfeiture of his goods. 24 Henry 8 ch. 5 (1532). In so saying, the statute settled an earlier ambiguity. Until its enactment, there was a question whether those who killed felons in defense of life and property (it being immaterial whose life or property were imperiled) should be liable to forfeiture and so receive the same treatment as those who killed in self-defense subsequent to a personal quarrel. $C f$. N. Hurnard, supra note 2, at $\mathbf{x}$.

4. Private citizens were only "partially" deputized because the killing remained excusable and pardonable rather than justifiable. As Pollock and Maitland have observed,

Altogether in our common law the sphere of justifiable homicide was very narrow, and the cases which fell within it were those which in old times would have been regarded less as cases of legitimate self-defense than as executions, for the fur manifestus had been ipso facto an outlaw. F. Pollock \& F. Maitland, 2 History of English Law 479 (2d ed. 1898 \& reprint 1968) (footnote omitted). The 1532 statute expressly removed the liability of such killers to forfeiture. In theory, other sorts of pardonable homicide (such as those by misadventure) continued to give rise to liability to forfeiture. By the 18 th century, however, judges commonly permitted juries to bring in verdicts of not guilty in order to obviate the liability to punishment and the need for pardon. J.F. Stephen concluded that " $[t]$ he law upon this subject may thus be considered as having fallen into desuetude in the course of the eighteenth century." J. STEPHen, History of the Criminal Law in ENGLand 76 77 (1883). He then summarized the statute of 1828 which provides that "no punishment or forfeiture shall be incurred by any person who shall kill another by misfortune, or in his own defence. or in any other manner without felony." Id.

5. Jury accounts of aggravated assaults which provoked a defensive killing often went to great lengths to establish that the defensive use of deadly force was necessary, apparently with the aim of increasing the chances that the king would grant a pardon. For example, there is the recounted jury verdict of a homicide proceeding against one Peter Wyth who killed Richard Faucun subsequent to Richard's aggravated assault against Peter.

Richard attacked Peter, striking him on the shoulder with a stick, which broke; Peter's own stick fell from his hand and Richard picked it up and chased him with it; Peter fled as far as he could to a certain dyke which he could not cross; turning back thence he fled to the muddy bed of a stream and went in up to the knees; Richard hit him again with his stick, which also broke, and then drew his knife and struck him through the arm, meaning to kill him. Peter repeatedly begged for mercy, but Richard would not spare him, but assaulted him more lethally. As Peter could not cross the stream without drowning nor escape elsewhere alive without defending himself, he drew his sword and struck Richard on the head.

N. HuRnard, supra note 2 , at 301 . 
encounter with a felon, however, things were different. Not only was there no duty to retreat, there was an affirmative obligation to use deadly force if the alternative were leaving a murderous felon at liberty. An innocent victim capable of defending himself who, instead, ran from a potential murderer, would be guilty of misprision. ${ }^{6}$

Commentators were careful to distinguish between a person who killed merely for the sake of his own skin, and a person who, in killing a felon, was performing a public benefit. Thus, the 1532 statute did not change the long standing legal requirement that those who killed in self-defense subsequent to a personal quarrel be punished by forfeiture of chattels.

In much of Europe, it was also a common requirement that those who killed only in defense of themselves (as opposed to those who killed on behalf of the whole community) be required to pay compensation to the decedent's relatives. ${ }^{7}$ Apparently, this requirement stemmed from the thought that even in cases of excusable homicide, some type of emendation was called for even if punishment was not appropriate. ${ }^{8}$ Although the practice of requiring compensation payments to the aggrieved relatives had fallen into disuse in England by the sixteenth century, on some parts of the continent the requirement continued in force until the seventeenth century. ${ }^{9}$ Requiring the king's pardon for homicide faded away in the eighteenth century, but the

6. R. Perkins, Perkins on Criminal Law 1003-04 (2d ed. 1969). Any guilt for misprision would not result in conviction, however. Clearly, the law put those who faced aggravated assault by felons in a difficult position. The 1532 statute relieved them of criminal liability. Furthermore, although required to employ deadly force against their felonious attackers, users of such force would be liable for an excusable homicide requiring the king's pardon to escape punishment.

I am indebted to Don B. Kates, Jr. for bringing this citation to my attention.

7. The compensation requirement may have been a holdover from Norman rule, under which homicide generally was treated as a private, compensable wrong unless it occurred in secret, "clanculo." Secret killings were a crime against the crown as well as a wrong against the decedent's relatives and the king was entitled to forfeiture while the victim's family was entitled to revenge and compensation. A special fund called a "murdrum" was established, resources for which were drawn from a tax upon districts where homicide was clanculo. The fund's purpose was to provide an incentive for reporting homicides (whether by misadventure or otherwise) of strangers, most of whom turned out to be Frenchmen. After 1267, the distinction between French and Anglo-Saxon homicides was lost and murdrum no longer applied in cases of death by misadventure. In England, killing in self-defense against a deliberate and aggravated assault had never given rise to a right of aggrieved relatives to compensation because any such right was forfeited by the crime or attempted crime. Killings in self-defense stemming from a quarrel, however, continued to be subject to courtimposed compensation for the family of the deceased and the king's official pardon was required. $C f$. N. Hurnard, supra note 2, at xii-xiv.

8. In such instances, the survivor was guilty of homicide se defendendo. "Where the law judges a man guilty of homicide se defendendo, there must be some precendent quarrel in which both parties always are, or at least may justly be supposed to have been, in some fault . . . ." 1 PLEAS OF THE Crown ch. 28, $\$ 24$ (Leach 6th ed. 1788). Blackstone distinguished between excusable, justifiable, and felonious homicide and placed se defendendo in the first category because he thought it carried with it some degree of guilt. When the practice of requiring compensation payments to the decedent's relatives ended, however, the significance of distinguishing between excusable and justifiable homicide was lost. Any residual guilt borne by a person who successfully plead selfdefense had no legal consequences. See $4 \mathrm{~W}$. Blackstone, Commentaries $186-88$ (Philadelphia 1803).

9. N. Hurnard, supra note 2 , at $\mathrm{xi}$. 
common law never relieved homicide defendants who pled self-defense of the burden of showing that they acted from necessity and without malice.

More recently, in the United States there has been movement away from the common law requirement that homicide defendants pleading self-defense bear the burden of showing that malice was not present. Currently, the majority of states require that prosecutors bear the burden of showing that defendants pleading self-defense acted with malice. ${ }^{10}$

What point is served by this brief legal history? It serves to sharpen the original question by pointing out that the law gradually has moved from a position which treated all killings by private individuals as wrongs of some sort to the point where all jurisdictions recognize a right to kill in self-defense. Is this movement something which a rational person should welcome? Would it be better to reinstate the position that all killings by private individuals are wrongs of some kind (even if some are excusable)? Would it be best of all to go further still and hold that no defensive killings by private individuals should ever be permitted? Obviously, these questions cannot be settled by seeking proper legal authorities (the older the better) who approve or disapprove (conditionally or unconditionally) of private lethal self-help. If the proper method is not to appeal to authorities or tradition, though, then how should one approach these questions?

Intuitions are not much help. Consider the following two cases. In the first, the question is raised whether $A$ should be permitted to employ lethal force against $B$ solely on the grounds that $B$ has a capacity or is acquiring a capacity which is used by fifty percent of those who possess it to mount deadly attacks. In the second, it is asked whether $A$ should be permitted to employ preemptory lethal force against $B$ solely on the grounds that $B$ has announced his firm intention to attack $A$ on the day when his ( $B^{\prime}$ 's) spinning of a roulette wheel drops the ball on the number twenty-five. Would the answers to these questions become more intuitively clear if the strategy Plato uses in The Republic were employed and the situations were "writ large" with the stipulation that $A$ and $B$ stand for states? If there were a defensible judgment about the permission to use preemptory lethal force in one case or another, it would not hinge solely on a difference between the probabilities involved.

The primary concern of this article is not with the marginal complexities of the law on self-defense. The questions raised here instead concern the desirability of having a conditional lethal self-help rule of any sort and whether a single theory can account for relieving from criminal liability a legitimate defender who kills an innocent third party in the process of exercising his conditional permission. To deal with this type of case rationally, a theory is needed which makes it possible to distinguish good normative inferences from bad ones-a theory which allows coherent, comparative judgments about the desirability of alternative legal states of affairs. What theory fits this description?

10. See Annot., 43 A.L.R.3d 221 (1972). 
Professor Polsby believes that the theory should be utilitarian. ${ }^{11}$ He thinks that this point of view provides reasons to prefer a broad conditional permission to kill in self-defense to an unconditional prohibition against the private use of lethal force. ${ }^{12}$

Of the many fascinating questions which Professor Polsby's paper raises, two are addressed here. First, what reasons does he have for thinking that utilitarianism is the best theory? Second, what reasons does Professor Polsby have for thinking that conditional legal permission to use lethal force in selfdefense is better than an unconditional prohibition of it?

\section{WHY UTILITARIANISM?}

The basic precept of utilitarianism is providing the greatest good for the greatest number. Described more precisely, utilitarianism is a normative moral theory in which the good is made prior to the right; that is, criteria for judging what is worthwhile are independent of and prior to judgments about what people are duty-bound to do. If happiness is of supreme value, then people are duty-bound to bring about as much of it as possible. Thus, as a theory of obligation (telling people what they are duty-bound to do), utilitarianism asserts that one must bring about the state of affairs which, of all those feasible, contains at least as much total value (or as high an average value) as any available alternative. Utilitarianism presupposes the existence of a concrete method which enables computation of value aggregates interpersonally and calculation of total or average value for society as a whole. It is also a maximizing theory, which requires every feasible marginal gain in value to be brought up to the point where the costs of efforts to do so promise no net gain.

Utilitarians tend to regard legal liberties, claims, powers and immunities as instrumental social values (because of their causal connection with the production of happiness or welfare). In addition, utilitarians prefer that these entitlements be distributed in such a way that they maximally contribute to social welfare. Individuals hold entitlements not on their own account, but because of the resulting social advantages. Whether private individuals should be permitted to kill in self-defense and, if so, under what conditions, will be determined solely by the probable social welfare effects. The same will be true when determining criminal liability for killing innocent third parties and the allocation of burden of proof requirements in criminal proceedings.

All deontological theories contrast with utilitarianism; they all deny what utilitarianism asserts. Specifically, they deny that the sole right-making characteristic of actions, rules, or laws is the causal role they play in maximizing either total or average welfare. Actions, roles, or laws can be

11. See Polsby, Reflections on Violence, Giuns, and the Defensize L'se of Lethal Forre, Lall \& Contramp. Probs., Winter 1986, at 89, 94.

12. It. at $96,98-110$. 
right because of the way they distribute good or evil. For example, some deontological theories hold that there is an obligation to give people what they deserve independent of any obligation to maximize total or average utility. For such theories, to whom things happen matters without regard to any effect there may be on what happens to aggregate social welfare. A rule permitting a woman to repel a rapist by resorting to lethal self-help would be justified on the grounds that it apportions desert in accordance with viciousness. That such a rule would have a deterrent effect upon potential rapists is serendipitous.

Other deontological theories eschew the goal of designing social institutions to apportion good and evil according to virtue and vice. Contractarian theories hold instead that just social institutions are those which would be agreed to by rational, self-interested persons under conditions designed to ensure impartiality. Under this view, a lethal self-help rule would be justified if a rational, self-interested person would prefer the rule to its denial when provided with the knowledge that society contains aggressors but in ignorance of whether he himself were peaceable or an aggressor. For contractarians, it is not the inherent worthiness of rules that confers whatever binding force they have. Their binding force derives rather from an argument that they would be chosen under the appropriate circumstances.

Manifestly, the reasoning involved in proving which rule self-interested persons would agree to is a different project from determining which rules would tend to maximize aggregate utility. For the contractarian, those rules have morally binding force which would be agreed to by rational, selfinterested persons under conditions designed to be fair. If a rule would not be agreed to under the relevant conditions, its welfare maximizing tendencies (if any) give it no independent standing in moral argument. ${ }^{13}$

For what reasons does Professor Polsby prefer utilitarianism? Part of the answer seems to be that deontological theories lead to asking questions about defensive lethal force in the "wrong" way, that is, in an unfruitful way. As an example of an unfruitful way to pose the question, Professor Polsby offers the following: "[W] hy should an apparently lethal attacker forfeit his life [to his intended victim]" ? 14 After all, if the person is insane or is acting from an extreme mistake of fact, he does not deserve to be killed for it. As Polsby is quick to point out, however, putting the question in terms of desert misses the mark. The law does not require that an attacker let his victim take his life; neither does any deontological theory. Therefore, this question is the wrong manner in which to frame the inquiry but it constitutes no argument against a distinctively deontological way of asking.

In Professor Polsby's next example of how deontological theories ask questions in an unfruitful manner, concepts distinctive of some of these

13. The best-known contemporary version of this theory is found in J. RawLs, A THEORY or Justice (1971).

14. Polsby, supra notc 11 , at 93 (emphasis in original). 
theories are introduced-those of desert and rights. ${ }^{15}$ Polsby presents for consideration an attempted arrest of a suspected misdemeanant who resists in such a way that the officer defensively shoots and kills him. ${ }^{16}$ Professor Polsby claims it is not proper to say that police officers have a right to kill recalcitrant misdemeanants. ${ }^{17}$ Nor should it be said that such misdemeanants deserve to be killed for their "mulishness." Professor Polsby is surely correct in these claims-but what does that show about deontological theories? It seems perfectly natural to say (and Polsby seems to agree) that the officer had the right (that is, he was permitted on moral and legal grounds) to defend himself from reasonably expected harm by minimally sufficient means. On the other hand, it would be quite odd to say that the officer, in killing the misdemeanant, was innocent of wrongdoing because he was maximizing total (or average) expected utility. Of course, the utilitarian could say that the principle of utility provides a criterion for judging rules rather than actions. This argument is true enough, but the deontologist need not be limited to asking questions about self-defense in the moralistic terms Professor Polsby suggests. In sum, there is no reason for thinking that utilitarianism encourages one to ask more fruitful questions about social policy than deontological theories do.

The question that Polsby wants to ask is: "What lethal force rule will, over the long pull, produce the least amount of wrongful and (potentially) deadly violence in society?" A utilitarian could take an interest in finding out the right answer to this question, but he would not be the only one interested. A social contract theorist could be equally interested in an answer because rationally self-interested persons may choose to live under the violenceminimizing rule. It would remain for the contract theorist to prove that rational, self-interested persons would choose the violence-minimizing rule in order to have an argument for its adoption. Presumably, rational, selfinterested persons have an indirect interest in various policies' social welfare effects, but they are also interested in exercising and protecting their own autonomy. The moral relevance of the question for the contractarian consists in its interest for rationally self-interested persons who would be obligated to abide by those rules to which they freely consent. Similarly, a libertarian who supported a free market on the grounds that it was the only social arrangement which institutionalized freedom would be interested in an answer to Professor Polsby's question because he would think that the violence-minimizing rule would show proper respect for personal autonomy and enhance peaceable transactions as well.

Since each of the above theorists would be interested in Professor Polsby's question, it may be difficult to determine which theorist is the most natural candidate for answering the question. The strategy Polsby in fact employs in searching for an answer to his question, however, does not look distinctively

15. Id. at 94 .

16. $I d$.

17. Id. 
utilitarian. In fact, he admits as much when he abandons a task which would require gathering data and assigning cardinal values to outcomes and multiplying these values by their respective probabilities. ${ }^{18}$ In turning to rational choice models, Professor Polsby employs a strategy which seems most at home in a contractarian theory like the one advanced by John Rawls. Rawls is famous for his ambitious attempt to show how his two well-known principles of justice can be derived as theorems in the theory of rational choice under uncertainty. ${ }^{19}$ Perhaps one can interpret Professor Polsby's arguments as attempting to make it plausible to think that a conditional lethal self-help rule is a stable (or the least unstable) solution to a game theory model of aggression and that it should be preferred on that ground.

Professor Polsby argues for the preferability of a lethal self-help rule in two ways. ${ }^{20}$ Initially, he argues by appealing to the results of a computer simulation performed by Richard Dawkins in which five strategies regarding aggression compete against one another. It turns out that the "retaliator" strategy, one which involves reciprocity and retribution, beats strategies of determined aggression, threatened aggression, and pacificism (these are not Dawkins' labels). ${ }^{21}$

These results provide insight into the preferability of permitting lethal self-help as opposed to prohibiting it. In an environment which is known to contain aggressors, prohibiting lethal self-help penalizes the law-abiding by causing aggressors to fear defensive violence from the police only and not from their law-abiding victims. It seems objectionable for the law to permit aggressors to gain so much from their victim's disposition to be law-abiding.

A strict reciprocity rule is not, however, a lethal self-help rule. A lethal self-help rule permits those who reasonably believe themselves under deadly threat by an aggressor to "trump" the aggressor's threat by killing him. A strict reciprocity rule would permit a person who reasonably felt threatened to place his aggressor in a position to feel comparably threatened. In contrast, the lethal self-help rule is anticipatory and preemptory. Reciprocal threatening is not requried. The trump move may come as a complete surprise.

In his next argument, Professor Polsby appeals to recent work on the much studied two-person game called Prisoners' Dilemma. ${ }^{22}$ In the classic formulation of the game, it turns out that the strictly dominant strategy for each player, "never cooperate," results in making each party worse off than he would have been had the players been able to trust each other and cooperate. The situation changes, however, when the one-round game becomes an $\mathrm{n}$ round ("round robin") game. A computer simulation which placed more than six dozen strategies for Prisoners' Dilemma in competition showed that the

18. Id. at $110-11$.

19. See J. Rawl.s, supra note 13, at 1-192.

20. Polsby, supra note 11 , at $98-101$.

21. See R. Dawkins, Tue Selfish Gene $71-94$ (1976).

22. Professor Polsby relies on Axelrod \& Hamilton, The Evolution of Cooperation. 211 SCience 1390 (1981). 
simplest strategy, "TIT FOR TAT," submitted by Professor Rappaport, beat all the other strategies. ${ }^{23}$

A formal proof of the stability of TIT FOR TAT has been produced by Nigel Howard in his theory of metagames. ${ }^{24}$ This theory extends the concept of strategy to include one player's responses to possible strategy choices of his opponent, the opponent's responses in turn to the first player's conditional responses, and so on. Thus, a metastrategy is the strategy for selecting a strategy. Professor Howard proves that what was not a stable strategy in the original game becomes an equilibrium point in the n-player, n-level metagame expansion. Unfortunately, the noncooperative strategy is also an equilibrium. The practical importance of this result hinges upon the extent to which actual persons operate from a metagame point of view; it is probable that few do. 25

Professor Polsby notes several differences between the TIT FOR TAT strategy and our own lethal self-help rules. The most important dissimilarity he mentions is the one alluded to earlier; that is, unlike TIT FOR TAT, the citizen who reasonably believes himself under an aggressor's deadly threat may raise the stakes preemptorily and kill the aggressor. ${ }^{26}$

Unless it can be shown that lethal self-help rules are equivalent to TIT FOR TAT, the game theory results to which Professor Polsby refers are unavailing in his apology for the rules. He addresses this issue with the following argument:

The anticipatory rule is a translation, not a transliteration, of the TIT FOR TAT rule into real life. It rests on the assumption that the capacity to foretell the very shortrange future is an adequate substitute for awaiting the perfection of some harm. In other words, it supposes that the certainty of perfected action can be approached by anticipation when certain information is known. ${ }^{27}$

The argument seems to be: In close encounters of the lethal kind, requiring a defender to restrict himself to reciprocating an attacker's previous move leaves the defender without his full complement of moves. In such situations, the defender is permitted to replace reaction based upon certain knowledge about what the aggressor has already done, with preemption based upon knowledge of what the aggressor is likely to do next unless he is disabled.

This argument offers a good basis for supplementing TIT FOR TAT with lethal self-help rules but it is no proof that lethal self-help rules and TIT FOR TAT are equivalent. Although no attempt at proof is made here, it is probable that adding a lethal self-help rule to TIT FOR TAT would make a difference to the outcomes of games, and if this result is so, the two rules

23. Id. at 1393 .

24. N. Howard, Paradoxes of Rationality: Theory of Metagames and Political Behayior (1971),

25. For an excellent discussion of Howard's theory of metagames, see S. Brams. Paradoxes in Pol.itics (1976).

26. Polsby, supra note 11 , at 102.

27. Id. 
cannot be equivalent. Perhaps a justification (as opposed to a demonstration of equivalence) could be given by pointing to the unfairness of a rule which permitted one of the game's players to undertake a course of action which deprived the player's opponent of his full complement of moves without the opponent's consent.

It might be argued that rational, self-interested persons would not consent to play a potentially deadly game of TIT FOR TAT unless it were supplemented by a conditional lethal self-help rule. Two points, however, should be noted about this suggestion. Even if successful, the suggestion would not show that TIT FOR TAT and lethal self-help are equivalent, although it might be possible to derive both from some conception of fairness. Second, it is a contractarian way of arguing and not a utilitarian approach.

\section{III}

\section{Innocent Third Parties and Utilitarianism}

Professor Polsby presents his strongest argument for utilitarianism when he turns to the question of whether the law should permit legitimate defenders to escape criminal liability for injuring or killing innocent third parties in the course of using deadly force against an aggressor. He argues, quite correctly, that no account of deadly force which merely weighs the selfinterest of individuals could explain why the law fails to hold criminally liable persons who injure or kill innocent parties in the course of using otherwise privileged lethal self-help. It may not be hard to understand how the law could give the nod to the defender in a lethal encounter, but how could it fail to hold him criminally liable when his lethal act causes injury or death to innocent persons?

Professor Polsby thinks the answer must be sought by reference to public interests and not private ones:

The innocents cannot seek compensation from the defender because the defender's privilege is grounded on public necessity rather than on his private interest in selfpreservation. Put differently, the innocent is "compensated" ex ante because the rule that allows his safety to be suddenly appropriated yields a world that is, on average, a safer place for him to inhabit. ${ }^{28}$

There are difficulties with this explanation. Suppose that an attacker, in the hope of enhancing the success of his attack, seized an innocent third party and used that person as a shield in such a way that the defender could halt the attack only by shooting through the innocent shield. Further suppose that the law relieved the defender of criminal liability if he chose to perform the only act reasonably thought necessary to halt the attacker's deadly designs. If the law permitted this action, it would not be surprising if the law did not require the defender to use lethal self-help only in such a way as not to endanger bystanders, for if it did so require, it would have the effect of turning

28. Id. at 104 (footnote omitted). 
bystanders into partial innocent shields for the attacker even though he had not seized them. If a utilitarian justification is unnecessary to account for the first permission, it should not be necessary for the second. A principle of fairness would seem to recommend that the law refrain from imposing what would amount to a duty of heroic self-sacrifice on ordinary citizens (that is, those without special obligations in this regard, as in the case of police and soldiers). Thus, the ordinary citizen would not be required to refrain from the only means reasonably thought necessary to stop a deadly attack which was under way. Furthermore, since the law permits the ordinary citizen to escape criminal liability when, in acting from a reasonable but false belief, he kills someone who is in fact no threat, then by the same reasoning he should be relieved of liability to third parties whenever he acts reasonably.

Professor Polsby intriguingly suggests that the promise of a net public gain is needed to secure the defender's immunity from criminal liability for innocent parties he may injure or kill when exercising permissible lethal selfhelp. ${ }^{29}$ The background principle seems to be the Kaldor-Hicks efficiency criterion, which claims that one state of affairs is efficient (and therefore better) when compared to another if and only if those whose welfare increases at the expense of others could fully compensate those whose welfare diminishes. ${ }^{30}$ As it is usually conceived, the Kaldor-Hicks criterion does not require actual payment of compensation to those whose welfare diminishes. Professor Polsby suggests that in this case compensation actually is paid, but it is paid ex ante. ${ }^{31}$

If full compensation is actually paid (ex ante), then the immunity given to a defender on the grounds that it is Kaldor-Hicks-better would also be recommended as Pareto-better. ${ }^{32}$ One situation is Pareto-better than another, however, only in the case where at least one person's welfare is improved by moving to it and no one's welfare is made net worse. It is difficult to accept that the innocent third party who is killed is not made net worse-unless one supposes that the years of greater security enjoyed by the victim prior to his untimely death fully compensate him for the loss of a longer, if somewhat more insecure, life and that it would be judged so from the victim's point of view.

29. Id. at 104 .

30. See Kaldor, Welfare Propositions of Economics and Imerpersonal Comparisons of Ctility. 49 F.CON. J. 549,550 (1939).

31. Polsby, supra note 11 , at 104.

32. One situation is Pareto-better than another if and only if it makes at least one person better off and no one worse off. If those who gain as a result of the move from one situation to another gain enough so that after fully compensating those who lose they still prefer the second to the first. then the second situation is both Kaldor-Hicks-better and Pareto-better. Cf. Colcman. Efficipncy. Ltility. and I'ealth .Maximization. 8 Hofstra I. Rkv. 509, 513 (1980). 


\section{IV}

\section{Concluding Thoughts}

Professor Polsby's article clearly points out that when interests conflict, the position which the law takes on the matter by distributing entitlements will inevitably enrich one side and make the other side worse off. If the law conditionally permits citizens access to the means and permission to use lethal force in their own defense, then potential attackers are made worse off because they run the risk of facing law-abiding victims who are not as helpless as they might have been otherwise. This distribution of entitlements may deter some aggressors from undertaking attacks which would have been otherwise attractive. On the other hand, if the law unconditionally forbids lethal self-help, then potential attackers are made wealthier because they can assume that insofar as their potential victims are law-abiding, they pose no deadly threat. This result leaves total expectable costs of attractive attacks only marginally greater than those they already risk paying should legal authorities catch, convict, and incarcerate them. ${ }^{33}$

In sum, there is a problem with the way in which utilitarianism asks us to think about crime. It is tempting to think that reductions in or even an abolition of violent crime would be desirable on utilitarian grounds. A good utilitarian must be mindful, however, of the costs to be paid in the transition, and there would be significant social costs in reaching such a goal. A reduction or elimination of deadly encounters would put many law enforcement personnel out of work and might result in staffing law enforcement institutions with less able personnel. The market for securityoriented products would be adversely affected. Violence is a big business not only for those criminals whose activities make it all possible. All those who marginally benefit from the untimely death of the victims of violence would suffer a reduction in their opportunities. A utilitarian may believe that the social costs of criminal violence exceed the social costs of reducing or eliminating such violence, but apparently no utilitarian has attempted to prove this belief. Ideally, it should be unnecessary to prove first that the marginal costs of our current level of violence exceed the costs of moving to a substantially less violent state of affairs before we are justified in preferring the latter. It is impossible to believe that the "correct" theory of political morality requires that the utility functions of those who prefer to be predators should be weighed equally with those who prefer to be peaceful.

33. Expectable costs of attractive attacks are marginally greater than the disvalues of arrest. conviction, and jail multiplied by their respective probabilities because the attacker must allow some probability that his potential victim will not be law-abiding with respect to ownership of the means and employment of lethal self-help. There is always a legitimate question whether criminals actually engage in calculations of this sort. Evidence suggests, however, that they do. Sep Kleck, Policy L.essons from Recent Gun Control Research, Law \& Contemp. Probs., Winter 1986, al 35. 